\title{
THE RENAL EXCRETION OF INOSITOL IN NORMAL AND DIABETIC HUMAN BEINGS ${ }^{1}$
}

\section{By WILLIAM H. DAUGHADAY AND J. LARNER ${ }^{2}$ wITH THE TECHNICAL ASSISTANCR OF ELLABETH HOUGHTON}

\author{
(From the Departments of Medicine and Biological Chemistry, Washington University School \\ of Medicine, and Barnes and Homer Phillips Hospitals, St. Louis, Mo.)
}

(Submitted for publication July 2, 1953; accepted October 28, 1953)

The presence of increased amounts of inositol in the urine of patients with diabetes mellitus has been known for almost a century (1-3). The inosituria in diabetes mellitus has generally been attributed to polyuria because the excretion of inositol has also been reported to be high in patients with diabetes insipidus. Some experimental support for this hypothesis has been provided by Needham (4), who observed a moderate increase in the excretion of inositol by rats made polyuric by feeding salt while on a low inositol diet.

Understanding of the metabolism of inositol has been delayed in part by the lack of specific and sensitive analytical methods. A new analytical procedure was made possible by the observation of Eastcott (5) that certain strains of yeast require inositol for optimal growth. The resultant microbiological assay has permitted the estimation of microgram quantities of inositol with satisfactory accuracy. In this report the inosituria of diabetes is confirmed using the yeast microbiological assay, and observations in man relating this abnormality to glucosuria rather than polyuria are presented.

\section{METHODS}

\section{Inositol in urine}

Inositol was measured by the method of Atkin, Williams, Schultz, and Frey (6). Unknown solutions were tested in duplicate at three dosage levels. The turbidity produced by the growth of Saccharomyces carlsbergensis in the tubes containing the unknown solution was compared to that developed in tubes containing known amounts of inositol and incubated simultaneously. Duplicate tubes containing seven different concentrations of inositol were prepared for each assay. Treatment with Deeminite ${ }^{3}$ was introduced for the studies presented in Tables III and

1 This work was supported by a grant-in-aid from the Nutrition Research Foundation.

2 Fellow of the Life Insurance Medical Research Foundation: Present address, Division of Bio-Chemistry, University of Illinois, Urbana.

${ }^{3}$ Obtained from A. S. Aloe and used without purification.
IV to remove pigments, inhibitory substances 4 and virtually all salts. The procedure used for free inositol was as follows: A dilution of urine was made so that the inositol content was between 2 and 8 micrograms per milliliter. To $50 \mathrm{ml}$. of such diluted urine was added $7 \mathrm{Gm}$. of Deeminite. After shaking intermittently for 30 minutes the slurry was filtered and the filtrate was used directly for assay.

Glucose added to normal urine was without significant effect on inositol measurements (Table I). Representative recoveries from a normal urine of relatively high and a urine of low inositol content are given in Table II. The very low concentration of inositol in certain urines presented special problems of assay. Maximum values were occasionally noted in the tubes containing the least amount of test solution suggesting the presence of inhibitors. Purification of the inositol in such a urine has been carried out to determine whether inhibitors present in the urine had masked large amounts of inositol. Saturated lead acetate was added to diluted urine at a $\mathrm{pH}$ of about 6. The resultant precipitate was discarded. The $\mathrm{pH}$ of the supernatant solution was then adjusted to about 10 with concentrated ammonium hydroxide. After standing over night in an ice box the precipitate was collected and washed with absolute alcohol. Inositol was eluted from the precipitate with water acidified to $\mathrm{pH} 3$ with sulfuric acid. The resulting eluate was desalted with Deeminite and assayed for inositol. No evidence of unrecognized inositol was obtained and the purified solutions did not show inhibitory effects in the assay. Ninety-two per cent of added inositol was recovered from urine by this procedure (Table II).

The inositol of human urine exists almost exclusively in the free form as determined by assay before and after prolonged hydrolysis according to the method of Woolley (8). Loss of some inositol occurs under such drastic conditions and only from 50 to 93 per cent of added inositol was recovered. For these reasons most samples were assayed without hydrolysis.

\section{Inositol in plasma}

Total plasma inositol was measured by refluxing $4 \mathrm{ml}$. of plasma with an equal volume of concentrated hydro-

4 Choline has been shown to inhibit the microbiologic assay for inositol $(7,8)$. Because choline is present in only trace amounts in urine and Deeminite removes 99 per cent of choline added to distilled water, choline is not considered a significant inhibitor in these assays. 
TABLE I

Effect of urine glucose on inositol assay *

\begin{tabular}{ccccc}
\hline \hline $\begin{array}{c}\text { Urine } \\
\text { sample } \\
m l .\end{array}$ & $\begin{array}{c}\text { Glucose added } \\
m g . \text { per cent }\end{array}$ & \multicolumn{2}{c}{$\begin{array}{c}\text { Inositol found } \\
\text { mg./sample }\end{array}$} & mg./day \\
\hline 5 & 0 & 0 & 190 & 103 \\
5 & 50 & 1 & 198 & 108 \\
5 & 150 & 3 & 179 & 93 \\
5 & 300 & 6 & 169 & 91 \\
\hline
\end{tabular}

* The indicated amounts of glucose were added to $5 \mathrm{ml}$. of urine A. After diluting to $50 \mathrm{ml}$. with water the sample was desalted with Deeminite and analyzed for inositol.

chloric acid for 12 to 14 hours on a sand bath. The digest was evaporated to dryness at $100^{\circ} \mathrm{C}$. under reduced pressure with a stream of air. The residue was taken up in $20 \mathrm{ml}$. of water and was decolorized with Deeminite. Using the above method 75 per cent of inositol added to plasma was recovered.

Free inositol was determined in plasma by dialyzing $4 \mathrm{ml}$. of plasma in a cellophane bag against $25 \mathrm{ml}$. of distilled water at $8^{\circ}$ overnight. Aliquots of the dialysate were analyzed for inositol. Calculations were made on the assumption that the concentration after dialysis was equal inside and outside the bag. Eighty per cent of the inositol added to plasma could be recovered by this method.

\section{Clearance studies}

The renal clearance of endogenous creatinine was used as an index of glomerular filtration. Creatinine was measured by the method of Folin and Wu (9). Glomerular filtration determined in this manner was adequate for the purposes of this study. The inositol clearance was calculated from the free (dialyzable) plasma inositol and the free urine inositol values. Fifteen-minute urine collection periods were used and a sample of heparinized blood was obtained five minutes after the start of each collection pe- riod. One minute before the end of each period, $20 \mathrm{ml}$. of distilled water and $20 \mathrm{ml}$. of air were injected through the catheter. The contents of the bladder were expressed by suprapubic pressure.

\section{General technics}

The subjects for these studies were healthy medical students and patients on the wards of the Barnes Hospital and the Homer G. Phillips Hospital. Normal subjects were allowed to eat unrestricted diets and the diabetic patients ate standard diabetic diets. Strict dietary control of inositol intake was not attempted because information concerning the inositol content and availability of inositol in common foods is not at hand. A good mixed diet has been estimated to contain about $1 \mathrm{Gm}$. of inositol per day (10). Analysis of diabetic diets in this laboratory gave values between 300 and $900 \mathrm{mg}$. per day.

Toluene was used as a preservative for urine during collection. Aliquots of urine were refrigerated until assay. Urine sugar was measured by the method of Somogyi (11).

\section{RESULTS}

\section{Inositol excretion in normal subjects}

The daily inositol excretion in the urine by 11 non-diabetic subjects was measured. The results of 21 analyses gave a mean excretion of $37 \mathrm{mg}$. per day with a range of 8 to $144 \mathrm{mg}$. per day (Figure 1). Because of the frequent assertion that urine inositol is related to urine volume, the excretion of inositol has been plotted against the urine volume in Figure 2. The effect of oliguria produced by water restriction and polyuria by excessive hydration has been studied in two normal subjects. A

TABLE II

Recovery of inositol added to urine

\begin{tabular}{|c|c|c|c|c|c|}
\hline Urine & $\begin{array}{c}\text { Aliquot } \\
m l .\end{array}$ & $\begin{array}{c}\text { Inositol } \\
\text { added } \\
\boldsymbol{\mu g .} .\end{array}$ & $\begin{array}{l}\text { Preparation } \\
\text { of sample }\end{array}$ & $\begin{array}{c}\text { Inositol } \\
\text { Mg. aliquot }\end{array}$ & $\underset{\text { mg./day }}{\text { Found }}$ \\
\hline \multirow[t]{2}{*}{ A } & $\begin{array}{l}2 \\
2\end{array}$ & $\begin{array}{r}0 \\
100\end{array}$ & $\begin{array}{l}\text { Standard } \\
\text { Standard }\end{array}$ & $\begin{array}{r}72 \\
158\end{array}$ & $\underline{98}$ \\
\hline & & & & \multicolumn{2}{|c|}{$86 \%$ Recovery } \\
\hline \multirow[t]{2}{*}{ B } & $\begin{array}{l}5 \\
5\end{array}$ & $\begin{array}{r}0 \\
100\end{array}$ & $\begin{array}{l}\text { Standard } \\
\text { Standard }\end{array}$ & $\begin{array}{l}23(?) \\
138\end{array}$ & $13(?)$ \\
\hline & & & & \multicolumn{2}{|c|}{$115 \%$ Recovery } \\
\hline \multirow[t]{3}{*}{. } & $\begin{array}{l}10 \\
10\end{array}$ & $\begin{array}{r}0 \\
200\end{array}$ & $\begin{array}{l}\mathrm{Pb} \text { Precipitation* } \\
\text { Pb Precipitation* }\end{array}$ & $\begin{array}{l}<5 \dagger \\
189\end{array}$ & 一 \\
\hline & & & & \multicolumn{2}{|c|}{$92 \%$ Recovery } \\
\hline & 50 & 0 & Pb Precipitation* & 80 & 3.9 \\
\hline
\end{tabular}

* Purified by basic lead precipitation method described under Methods.

$\dagger$ Inositol content too low for accurate assay. 
TABLE III

The plasma level and urinary excretion of inositol after the oral ingestion of 3 grams of inositolnormal and diabetic subjects

\begin{tabular}{|c|c|c|c|c|c|c|c|c|c|c|c|}
\hline & & \multicolumn{4}{|c|}{ Plasma inositol, mg./100 ml. } & \multicolumn{3}{|c|}{ Urine inositol, mg./day } & \multicolumn{3}{|c|}{ Urine glucose, Gm./day } \\
\hline & & $0^{*}$ & 2 hrs.* & 4 hrs.* & 24 hrs.* & Day 1 & Day $2 \dagger$ & Day 3 & Day 1 & Day $2 \dagger$ & Day 3 \\
\hline \multicolumn{12}{|c|}{$\begin{array}{l}\text { Normal } \\
\text { subjects }\end{array}$} \\
\hline \multirow[t]{2}{*}{$\begin{array}{l}1 \\
2 \\
3 \\
4 \\
5\end{array}$} & & $\begin{array}{l}0.8 \\
0.8 \\
1.2 \\
1.1 \\
1.2\end{array}$ & $\bar{z}$ & $\begin{array}{l}0.9 \\
1.9 \\
1.6 \\
1.7 \\
2.5\end{array}$ & $\begin{array}{l}0.9 \\
1.0 \\
0.8 \\
0.9 \\
1.6\end{array}$ & $\begin{array}{r}37 \\
69 \\
103 \\
101 \\
-\end{array}$ & $\begin{array}{r}50 \\
181 \\
127 \\
146 \\
-\end{array}$ & $\begin{array}{l}35 \\
81 \\
96 \\
86 \\
-\end{array}$ & $\begin{array}{l}\bar{Z} \\
\overline{-}\end{array}$ & $\bar{z}$ & $\bar{z}$ \\
\hline & Mean & 1.02 & - & 1.72 & 1.02 & 78 & 101 & 75 & - & 一 & - \\
\hline \multicolumn{12}{|c|}{$\begin{array}{l}\text { Diabetic } \\
\text { subjects }\end{array}$} \\
\hline \multirow[t]{2}{*}{$\begin{array}{l}1 \\
2 \\
3\end{array}$} & & $\begin{array}{l}0.3 \\
0.8 \\
0.7\end{array}$ & $\begin{array}{l}1.3 \\
1.4 \\
3.8\end{array}$ & $\begin{array}{l}2.2 \\
1.9 \\
3.3\end{array}$ & $\begin{array}{l}1.1 \\
1.2 \\
0.9\end{array}$ & $\begin{array}{l}305 \\
304 \\
698\end{array}$ & $\begin{array}{c}660 \ddagger \\
563 \\
1299\end{array}$ & $\frac{471}{533}$ & $\begin{array}{r}>41 \\
82 \\
135\end{array}$ & $\begin{array}{r}63 \\
43 \\
147\end{array}$ & $\begin{array}{r}131 \\
40 \\
102\end{array}$ \\
\hline & Mean & 0.60 & 2.16 & 2.47 & 1.07 & 436 & 841 & 502 & 86 & 84 & 91 \\
\hline
\end{tabular}

* Hours after the ingestion of $3 \mathrm{Gm}$. of inositol.

$\dagger$ Inositol administered on Day 2.

\$ The urine collected during the first four hours after inositol administration was lost.

TABLE IV

The renal clearance of inositol

\begin{tabular}{|c|c|c|c|c|c|c|c|}
\hline \multirow[b]{2}{*}{$\begin{array}{l}\text { Patient ......... } \\
\text { Age. ......... } \\
\text { Surface area, }\end{array}$} & \multicolumn{2}{|c|}{ Normal } & \multicolumn{2}{|c|}{ Diabetic } & \multicolumn{3}{|c|}{ Normal and glucose } \\
\hline & $\begin{array}{l}\ldots \text { LK } \\
\ldots 20 \\
\ldots 1.74\end{array}$ & $\begin{array}{r}D M \\
25 \\
1.40\end{array}$ & $\begin{array}{l}\text { ES } \\
35\end{array}$ & $\begin{array}{r}\text { SW } \\
45 \\
1.69\end{array}$ & $\begin{array}{r}\mathrm{MJ} \\
48 \\
1.82\end{array}$ & $\begin{array}{r}\text { BB } \\
18 \\
1.48\end{array}$ & $\begin{array}{r}\text { LR } \\
25 \\
1.52\end{array}$ \\
\hline \multicolumn{8}{|l|}{ Control period I-15 minutes } \\
\hline $\begin{array}{l}\text { Inositol, plasma, mg. \% } \\
\text { Inositol, urine, } m g . \\
\text { Glucose, blood, mg. \% } \\
\text { Glucose, urine, Gm. } \\
\text { Clearance-Creatinine, ml./min. } \\
\text { Clearance-Inositol, ml./min. }\end{array}$ & $\begin{array}{l}0.62 \\
0.09 \\
- \\
\overline{96} \\
0.9\end{array}$ & $\begin{array}{l}0.52 \\
0.12 \\
- \\
78 \\
1.5\end{array}$ & $\begin{array}{c}0.56 \\
17.2 \\
517 \\
9.5 \\
165^{*} \\
205^{*}\end{array}$ & $\begin{array}{l}0.58 \\
10.2 \\
389 \\
2.6 \\
113 \\
117\end{array}$ & $\begin{array}{l}0.85 \\
0.21 \\
75 \\
92.005 \\
1.7\end{array}$ & $\begin{array}{l}0.31 \\
0.09 \\
79 \\
57^{.003} \\
1.9\end{array}$ & $\begin{array}{l}0.48 \\
0.10 \\
95 \\
93^{.010} \\
1.4\end{array}$ \\
\hline $\begin{array}{l}\text { Control period } I I-15 \text { minutes } \\
\text { Inositol, plasma, mg. } \% \\
\text { Inositol, urine, mg. } \\
\text { Clearance-Creatinine, ml./min. } \\
\text { Clearance-Inositol, ml./min. }\end{array}$ & & & & & $\begin{array}{c}0.95 \\
0.32 \\
88 \\
2.3\end{array}$ & $\begin{array}{c}0.32 \\
0.15 \\
79 \\
3.3\end{array}$ & $\begin{array}{c}0.52 \\
0.10 \\
103 \\
1.3\end{array}$ \\
\hline Loading period $I-15$ minutes & \multicolumn{4}{|c|}{ Inositol loading } & \multicolumn{3}{|c|}{ Glucose loading } \\
\hline $\begin{array}{l}\text { Inositol, plasma, mg. \% } \\
\text { Inositol, urine, } m g . \\
\text { Glucose, blood, } m g . \% \\
\text { Glucose, urine, Gm. } \\
\text { Clearance-Creatinine, ml./min. } \\
\text { Clearance-Inositol, ml./min. }\end{array}$ & $\begin{array}{l}56 \\
764 \\
\overline{76} \\
91\end{array}$ & $\begin{array}{r}75 \\
697 \\
\overline{-} \\
65 \\
62\end{array}$ & $\begin{array}{c}57 \\
1452 \\
497 \\
5.8 \\
71 \\
170\end{array}$ & $\begin{array}{r}58 \\
1215 \\
375 \\
2.1 \\
105 \\
139\end{array}$ & $\begin{array}{c}1.2 \\
9.6 \\
393 \\
3.6 \\
85 \\
53\end{array}$ & $\begin{array}{l}0.44 \\
5.3 \\
568 \\
2.8 \\
72 \\
80\end{array}$ & $\begin{array}{c}0.53 \\
5.5 \\
782 \\
6.8 \\
93 \\
69\end{array}$ \\
\hline Loading period II-15 minutes & \multicolumn{4}{|c|}{ Inositol lcading } & \multicolumn{3}{|c|}{ Glucose loading } \\
\hline $\begin{array}{l}\text { Inositol, plasma, mg. \% } \\
\text { Inositol, urine, } \mathrm{mg} . \\
\text { Glucose, blood, } \mathrm{mg} . \% \\
\text { Glucose, urine, } \mathrm{Gm} . \\
\text { Clearance-Creatinine, ml./min. } \\
\text { Clearance-Inositol, ml./min. }\end{array}$ & $\begin{array}{r}51 \\
\frac{852}{-} \\
135 \\
112\end{array}$ & $\begin{array}{r}70 \\
621 \\
- \\
59 \\
60\end{array}$ & $\begin{array}{c}53 \\
884 \\
506 \\
4.1 \\
60 \\
111\end{array}$ & $\begin{array}{c}48 \\
716 \\
355 \\
1.6 \\
97 \\
100\end{array}$ & $\begin{array}{c}1.4 \\
9.0 \\
334 \\
2.5 \\
78 \\
43\end{array}$ & $\begin{array}{l}0.54 \\
4.2 \\
550 \\
2.5 \\
74 \\
52\end{array}$ & $\begin{array}{c}0.66 \\
9.6 \\
588 \\
6.2 \\
104 \\
97\end{array}$ \\
\hline
\end{tabular}

* The high clearances in this period can be attributed to faulty urine collection. The ratio of inositol to creatinine clearance should be unaffected. 
INOSITOL EXCRETION BY NON-DIABETICS

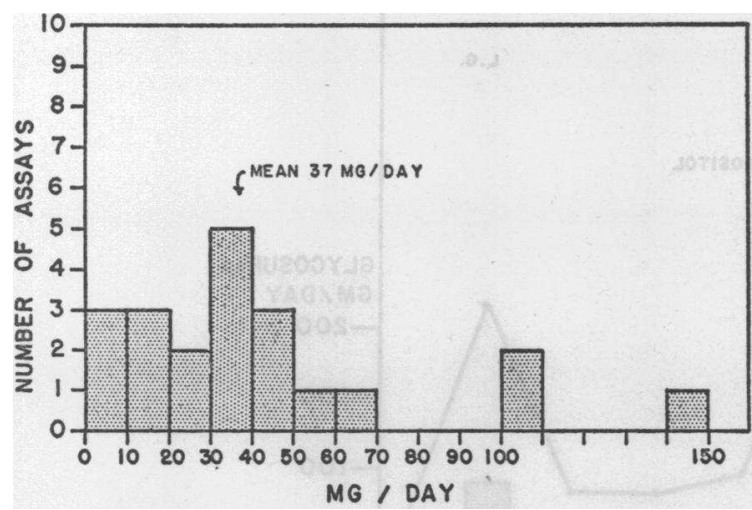

Fig. 1. The Urinary Excretion of InOSItol by 11 Non-Diabetic Subjects on Restricted Diets

three-fold increase in urine volume produced only an insignificant increase in urine inositol. Much more inositol was found in the urine of diabetic subjects with glycosuria in excess of $75 \mathrm{Gm}$. a day than in the urine of non-diabetic subjects at comparable urine volumes (Figure 2).

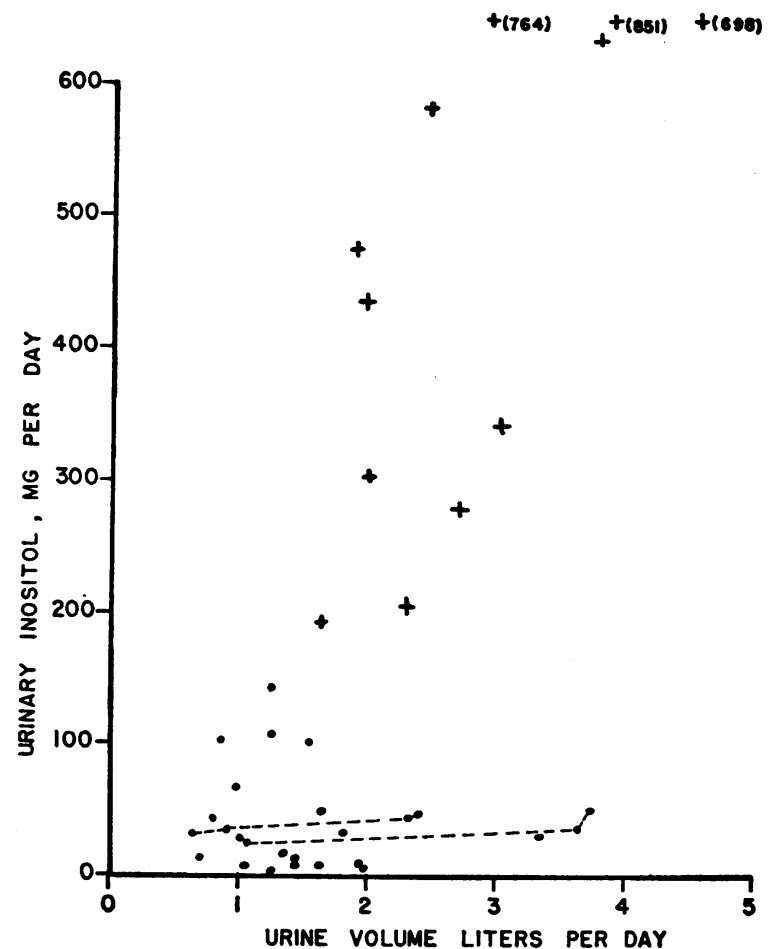

Fig. 2. The DaIly Excretion of Inositol by NonDiabetic (๑) and Diabetic $(t)$ Subjects Plotted AGAINST URINE VolUME

The broken lines connect values from the same individual during water restriction and over-hydration.

\section{Inositol excretion in diabetes}

Repeated observations have been made of the daily inositol excretion of seven hospitalized patients with uncontrolled diabetes mellitus. From 280 to $851 \mathrm{mg}$. per day of inositol were excreted during severe glycosuria. One representative subject (Figure 3) was given decreasing doses of insulin until the urinary excretion of glucose increased to more than $100 \mathrm{Gm}$. per day. The inositol in the urine was measured both with and without hydrolysis and the results agreed within the accuracy of the method. During the period of uncontrolled diabetes, large amounts of inositol were present in the urine. Upon reinstitution of insulin treatment, the excretion of inositol fell to the normal range.

A second representative case, (Figure 4) exhibited severe glycosuria during a period of insulin resistance. Before insulin therapy became effective between 479 and $851 \mathrm{mg}$. of inositol were excreted daily. With improved diabetic control, the inositol excretion fell. The urine volume in both of these cases did not exceed 3.8 liters despite glycosuria in excess of $100 \mathrm{Gm}$. per day.

\section{Inositol load experiments}

The effect of the oral ingestion of inositol on plasma concentration and urinary excretion has been studied. After a control day, a single dose of 3

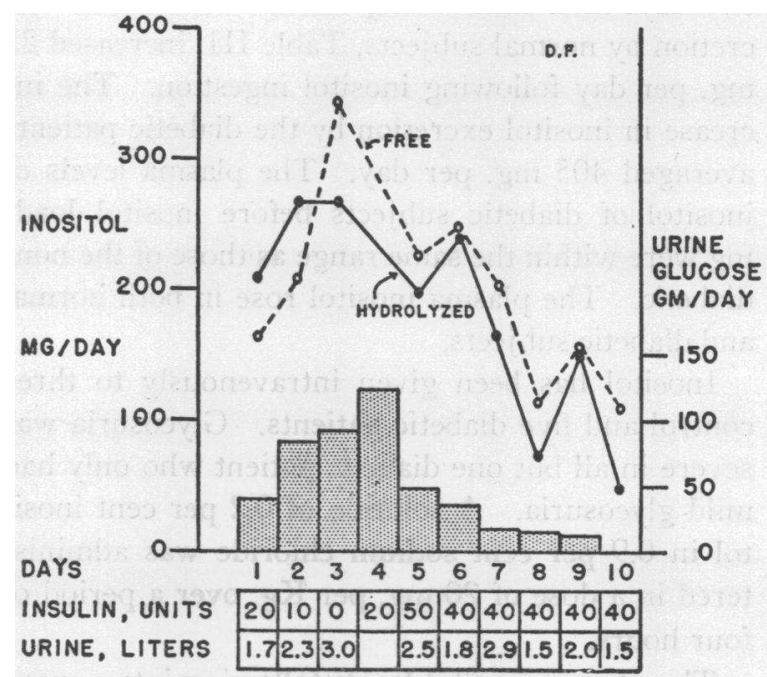

Fig. 3. The Daily Excretion of Free and Hydrolyzable Inositol by a Representative Patient with Uncontrolled Diabetes

The excretion of glucose is shown in the shaded columns. 


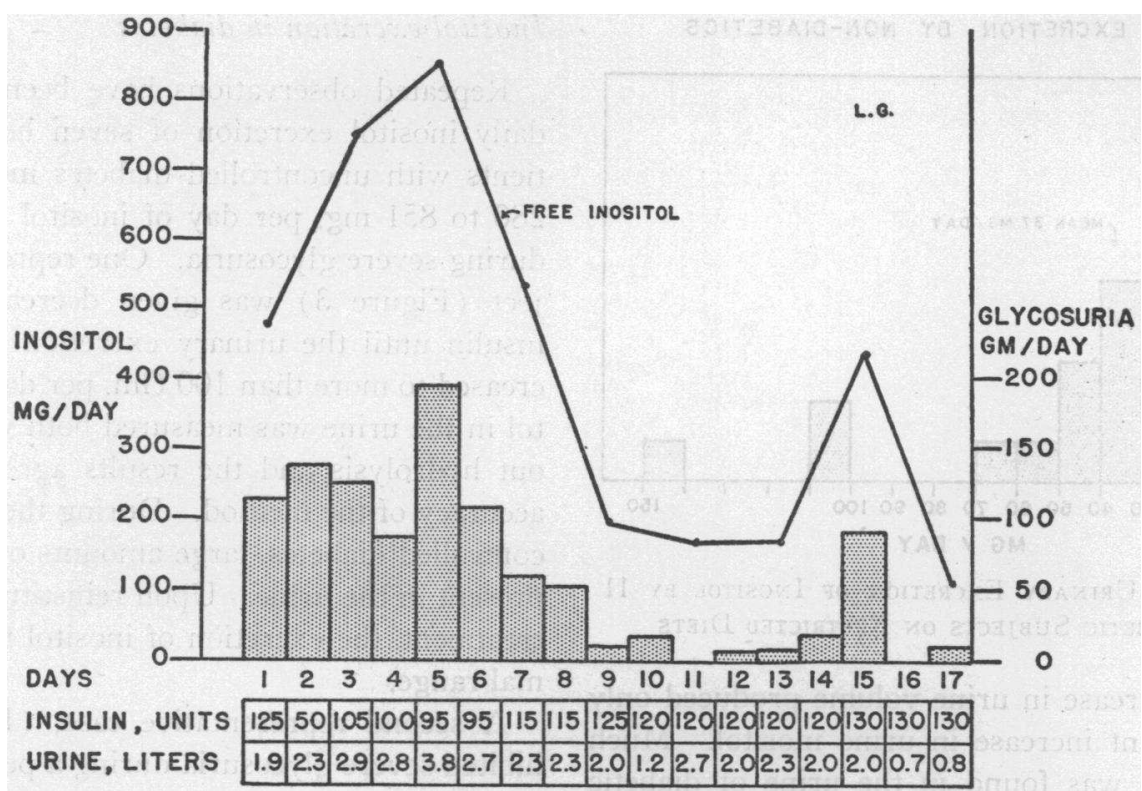

Fig. 4. The Daily Excretion of Inositol by a Second Representative Patient With UNCONTROLled Diabetes

The excretion of glucose is shown in the shaded columns.

$\mathrm{Gm}$. of inositol dissolved in $200 \mathrm{ml}$. of tap water was given by mouth on the morning of the second day. This dose of inositol was estimated to be from three to five times the normal dietary intake. Breakfast was omitted, but, thereafter, the subjects were allowed to eat their regular diet. The inositol excretion was measured on the control day and on the two days after inositol ingestion. The inositol excretion by normal subjects, Table III, increased 23 mg. per day following inositol ingestion. The increase in inositol excretion by the diabetic patients averaged $405 \mathrm{mg}$. per day. The plasma levels of inositol of diabetic subjects before inositol loading were within the same range as those of the nondiabetic. The plasma inositol rose in both normal and diabetic subjects.

Inositol has been given intravenously to three control and five diabetic patients. Glycosuria was severe in all but one diabetic patient who only had mild glycosuria. A solution of 0.2 per cent inositol in 0.9 per cent sodium chloride was administered in a dose of $20 \mathrm{mg}$. per $\mathrm{Kg}$. over a period of four hours.

The plasma inositol levels following intravenous administration of inositol were essentially similar when measured either by the hydrolysis or dialysis techniques. Only the results obtained by the latter method have been used in plotting Figure 5. The plasma inositol level rose 200 to 400 per cent in both diabetic and control subjects during the infusion and promptly fell after the end of the infusion.

The diabetic patients excreted much more inositol than the control subjects on the preinfusion day. The inositol increment on the day of inositol infusion amounted to 36 per cent of the administered dose in the diabetic and only 13 per cent in the normal subjects. On the day after inositol infusion, the excretion in the urine had returned nearly to the control level in both groups.

\section{The renal clearance of inositol}

The clearance of endogenous creatinine and inositol have been measured in two diabetic and two non-diabetic patients. Endogenous inositol clearance was very low in the two normal subjects and high in the two diabetic subjects, approximately equivalent to creatinine clearance (Table IV). The inositol clearance at high plasma levels of inositol has been measured. Seventy milliliters of 10 per cent inositol was given rapidly by vein. The loading dose was followed by the injection of a sustaining solution containing one per cent inositol in isotonic saline given at a rate of $4 \mathrm{ml}$. per minute. After a five-minute equilibration period inositol 
THE INTRAVENOUS ADMINISTRATION OF INOSITOL
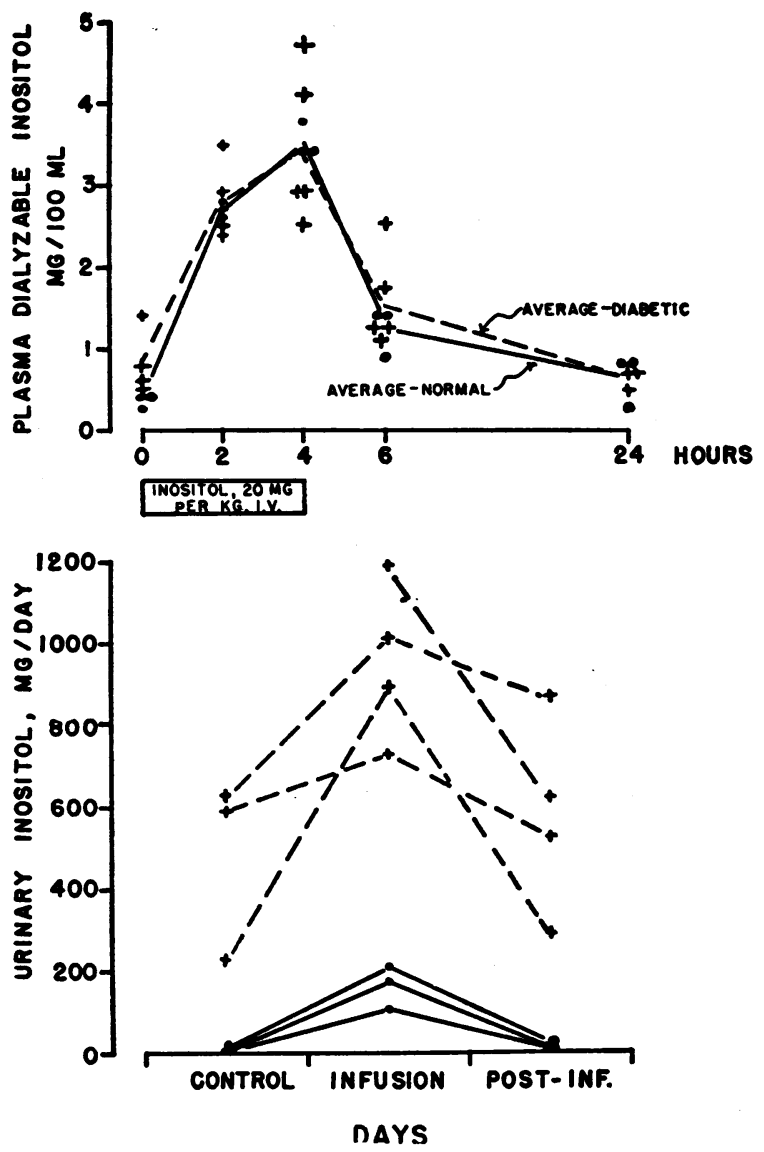

Fig. 5. Changes in Plasma Dialyzable Inositol AND URINe INOSITOL EXCRETION BEFORE AND AFTER THE Intravenous Administration of 20 Mg. PER Kg. Body WEIGHT OF INOSITOL FOR FOUR HOURS

Values obtained from diabetic patients are indicated by $(+)$, those for normal patients by $(\bullet)$.

and creatinine clearances were determined. With plasma inositol levels between 51 and $75 \mathrm{mg}$. per $100 \mathrm{ml}$. the clearance of inositol rose to levels comparable to creatinine clearance in both normal and diabetic subject.

The effect of glucose loading on inositol excretion has been studied in three non-diabetic subjects. One half-hour prior to the clearance measurements the patients received $3 \mathrm{Gm}$. of inositol by mouth. The inositol clearance of these subjects was low during the control period (Table IV). Glucose loading was performed by the rapid intravenous administration of 50 per cent glucose in a dose of $2 \mathrm{ml}$. per $\mathrm{Kg}$. of body weight for M. J. and $21 / 2 \mathrm{ml}$. per $\mathrm{Kg}$. of body weight for the other two subjects. When the priming dose of glucose had been given, a sustaining solution of 20 per cent glucose was started at a rate of $4 \mathrm{ml}$. per min. and was continued for two 15-minute clearance periods. A sustained hyperglycemia and glycosuria were achieved in these patients. A 30-fold increase in inositol clearance occurred during glucose infusion.

\section{DISCUSSION}

The present observations confirm earlier reports of an increased urinary excretion of inositol in human diabetes mellitus. Since urine volume correlated poorly with inositol excretion in non-diabetic subjects, other causes of the inosituria have been sought.

These studies indicate that an alteration of renal function is responsible for the inosituria of diabetes. Filtered inositol is almost completely reabsorbed at physiologic plasma levels in normal subjects. With plasma levels of inositol between 51 and $75 \mathrm{mg}$. per $100 \mathrm{ml}$., the ability of the tubule to reabsorb inositol is exceeded, and inositol clearance approaches the rate of filtration. A striking difference exists in patients with diabetes mellitus. Large amounts of inositol are excreted even at normal levels of plasma inositol. The renal clearance of inositol in non-diabetic subjects rose greatly when a massive load of glucose was presented to the renal tubules. It would seem clear that glucose increases the excretion of inositol probably by inhibiting the reabsorption of inositol by the human renal tubule.

A comparable situation exists in the reabsorption of xylose by the renal tubule. Glucose and phlorizin have been found to block the reabsorption of xylose suggesting that glucose and xylose may share the same transport mechanism (12). Phlorizin also inhibits the reabsorption of inositol by the renal tubules in rats (13). At low plasma levels the reabsorption of inositol by the renal tubules is much more complete than the reabsorption of xylose. As the plasma level is raised the renal clearance of both substances approaches the rate of glomerular filtration. Further study is necessary to establish the relation between inositol and glucose transport mechanisms. 


\section{SUM MARY}

1. The urine of 11 non-diabetic subjects contained an average of $37 \mathrm{mg}$. of inositol per day (range 8 to $144 \mathrm{mg}$.). Urine volume correlated poorly with inositol excretion.

2. Seven uncontrolled diabetic patients had a urinary excretion of from 280 to $851 \mathrm{mg}$. per day of inositol. The inosituria of diabetes disappeared after the control of glycosuria.

3. A small rise in the plasma level of inositol occurred following the ingestion of $3 \mathrm{Gm}$. of inositol in both diabetic and non-diabetic subjects. The average increase in urinary excretion on the day of inositol ingestion was $23 \mathrm{mg}$. in the control group and $405 \mathrm{mg}$. in the diabetic group.

4. Diabetic subjects excreted three times more inositol in their urine than did non-diabetic subjects following the slow intravenous administration of $20 \mathrm{mg}$. per $\mathrm{Kg}$. of inositol but the levels of plasma dialyzable inositol were the same in the two groups.

5. The renal clearance of inositol in normal subjects at physiologic plasma levels of inositol was low. A 3000 per cent increase in inositol clearance occurred following glucose loading at normal plasma inositol levels. At high plasma inositol levels clearance rose to the level of endogenous creatinine clearance. The renal clearance of inositol in diabetic subjects was high even at normal plasma inositol levels.

6. It is concluded that a renal tubular mechanism for the reabsorption of inositol exists and that tubular transport of inositol is inhibited by high glucose loads. The inosituria of diabetes mellitus can be attributed to an increased inositol clearance produced by glycosuria and not by polyuria.

\section{ACKNOWLEDGMENTS}

The authors wish to acknowledge the assistance of Mrs. M. Heady, laboratory technician, and Miss S. Wood, research nurse, in the performance of this study.

The pyrogen-free inositol for parenteral use was generously provided by Dr. H. J. Byrne of the Commercial Solvents Corporation, Terre Haute, Indiana.

\section{REFERENCES}

1. Vohl, H., Uber des Auftreten des Inosits in Harn bei Nieren-krankheiten und die Verwandlung des Diabetes mellitus in Diabetes inositus. Arch. Physiol. Heilh., 1858, n.f. 2, 17, 410.

2. Neukomm, J., Ueber das vorkommen von Leucin, Tyrosin und anderer Umsatzstaffe im Menschlichen Körper bei Krankheiten. Zurich, Otell, Füssli u. Comp., 1859, p. 48 (Dissertation) (quoted by Needham, J.).

3. Gallois, F.-N., De Pinosurie, Paris, J.-B. Baillière, 1864 , p. 61 (quoted by Needham, J.).

4. Needham, J., Studies on inositol. II. The synthesis of inositol in the animal body. Biochem. J., 1924, 18, 891.

5. Eastcott, E. V., Wildiers' bios, the isolation and identification of "Bios I." J. Phys. Chem., 1928, 32, 1094.

6. György, P., ed., Vitamin Methods, Volume I, New York, Academic Press, 1950.

7. Taylor, W. E., and McKibbin, J. M., The determination of lipide inositol in animal tissues. J. Biol. Chem., 1953, 201, 609.

8. Woolley, D. W., The determination of inositol. Biol. Symposia, 1947, 12, 279.

9. Folin, O., and Wu, H., A system of blood analysis. J. Biol. Chem., 1919, 38, 81.

10. Williams, R. J., The approximate vitamin requirements of human beings. J. A. M. A., 1942, 119, 1.

11. Somogyi, M., A rapid method for the estimation of urine sugar. J. Lab. \& Clin. Med., 1941, 26, 1220.

12. Smith, H. W., The Kidney: Structure and Function in Health and Disease, New York, Oxford University Press, 1951.

13. Daughaday, W. H., and Larner, J., Unpublished experiments. 